\title{
Hypophosphataemia and Hyperphosphataemia in a Hospital Population
}

\author{
M. G. BETRO, R. W. PAIN
}

British Medical fournal, 1972, 1, 273-276

\section{Summary}

One hundred cases of hypophosphataemia $(<2.0 \mathrm{mg} / 100$ $\mathrm{ml}$ ) and 84 cases of hyperphosphataemia $(\geqslant 5.0 \mathrm{mg} / 100 \mathrm{ml})$ occurring in a hospital population were studied in order to determine the cause of the abnormality. Examples of hyperphosphataemia due to renal failure were excluded from the study.

A low serum phosphorus concentration was most frequently due to intravenous administration of carbohydrate, usually glucose, which accounted for $\mathbf{4 0} \%$ of cases. The next commonest cause was vomiting (12\%). No obvious explanation could be found in $26 \%$ of cases, but in most of these factors were present which are known to affect phosphorus metabolism.

No one cause of hyperphosphataemia was outstanding in frequency and in over $50 \%$ of cases no definite explanation for the abnormality could be found.

\section{Introduction}

At the present time the main use made of a serum phosphorus estimation is in the diagnosis of abnormalities of parathyroid function. However, many other factors besides parathyroid disease affect the serum level of this substance. In spite of this, many textbooks of chemical pathology pay only brief attention to the various causes of a raised or lowered serum phosphorus level in contrast to the large amount of space devoted to changes in serum calcium concentration (Fourman and Royer, 1968; Henry, 1969; Fraser and MacIntyre, 1970; Hoffman, 1970). A recent editorial (Lancet, 1970) stated that "despite the central role of phosphate in the ADP-ATP system and its importance as a major constituent of bone and teeth, as well as a urinary buffer, phosphate homoeostasis has received surprisingly little attention."

With the advent of multichannel screening the opportunity has arisen of studying changes in serum phosphorus and their causes in a large number of patients who previously would not have had this test performed. We report here an analysis of 100 cases of hypophosphataemia and 84 cases of hyperphosphataemia encountered in a hospital population. Because of the preponderance of renal failure as a cause of hyperphosphataemia it was decided to exclude patients with this disorder from the study. Outpatients were also excluded as, in general, they could not be satisfactorily followed up.

\section{Methods}

Each serum phosphorus estimation was one of a batch of 12 estimations performed with the Technicon SMA 12/60 AutoAnalyzer on sera which had been separated as soon as possible after the blood samples had been taken. Each day the results were examined and all examples of serum phosphorus levels of

Institute of Medical and Veterinary Science, Adelaide, South Australia, $\mathbf{5 0 0 0}$

M. G. BETRO, M.B., CH.B., F.R.C.P.A., Assistant Medical Biochemist R. W. PAIN, M.B., B.S., F.R.C.P.A., Assistant Medical Biochemist
$2.0 \mathrm{mg} / 100 \mathrm{ml}$ or less or $5.0 \mathrm{mg} / 100 \mathrm{ml}$ or more were noted. These levels are three standard deviations on either side of the mean normal level and were chosen as the limits of the normal range for the purposes of this study because the specimens were taken at all times during the day and both before and after meals. It has been shown that there is a diurnal variation in the level of serum phosphorus, though it usually remains between 3.0 and $4.5 \mathrm{mg} / 100 \mathrm{ml}$ (Carruthers et al., 1964; Mills, 1966). In addition, the eating of a meal has been shown to have a mild effect on serum phosphorus; within $\mathbf{4 5}$ minutes there is a mean fall to $0.25 \mathrm{mg} / 100 \mathrm{ml}$ below the fasting level, but by two hours there is a mean rise to $0.08 \mathrm{mg} / 100 \mathrm{ml}$ above the fasting level (Annino and Relman, 1959). The patients with abnormal levels were later visited in the wards and the case notes examined for an explanation of the abnormality.

When, after three months, we had obtained 100 cases of hypophosphataemia the number of examples of a raised phosphorus level in the absence of uraemia was only 60 . Therefore, in order to increase the number of the latter, we obtained from our computer (in which all results are stored) all examples of hyperphosphataemia for the month preceding the collection period. This gave a total of $\mathbf{8 4}$ non-uraemic cases for a fourmonth collection period. During the original collection period (three months), among 5,015 serum phosphorus estimations performed on inpatients there were 108 examples of hypophosphataemia $(2 \cdot 15 \%)$ from 100 patients (53 males and 47 females). The total number of estimations for the extended (4-month) period was 6,684, with 117 examples of non-uraemic hyperphosphataemia $(1.75 \%)$ from 84 patients (41 males and 43 females). In 1,001 estimations performed on outpatients during the 3-month period the incidence of hypophosphataemia was $0.9 \%$ and of hyperphosphataemia without uraemia $1.5 \%$.

The method for serum phosphorus estimation on the Technicon SMA $12 / 60$ is based on the production of phosphomolybdic acid, which is then reduced by stannous chloridehydrazine. The linearity of the phosphorus channel is regularly checked with aqueous standards and quality control sera at several different concentrations. Estimations of the potassium and bicarbonate content of sera from many of the patients were performed on the Technicon SMA 6/60, standardization of which is carried out in the same manner as for the $12 / 60$. The normal range for serum potassium in this laboratory is $4 \cdot 0-5 \cdot 5$ $\mathrm{mmol} / 1$., and for the purposes of the study a level of less than $4.0 \mathrm{mmol} / 1$. was regarded as indicating hypokalaemia. The corresponding figure for the definition of alkalosis was a bicarbonate level of greater than $31 \mathrm{mmol} / \mathrm{l}$. in the absence of respiratory insufficiency.

\section{Results}

\section{HYPOPHOSPHATAEMIA}

In 74 of the 100 cases the reduced serum phosphorus level could be attributed to a definite cause (Table I). In a number of instances two or more factors were operating simultaneously; in such cases if carbohydrate was being administered (or, in its absence, if the patient was vomiting) this was regarded as the main cause and the others as contributory (Table II). Thus though there were three patients with Gram-negative septicaemia the hypophosphataemia was considered to be primarily due to intravenous carbohydrate in one and to vomiting in another. 
TABLB I-Main Causes of Hypophosphataemia in 100 Cases
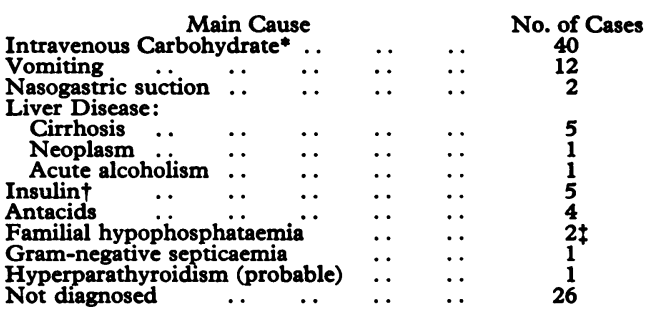

-Usually 4-5\% glucose; occasionally $50 \%$ glucose or $10-50 \%$ fructose given in association with aminofusin.

$\ddagger$ Mother and daughter.

TABLE II--Secondary Causes of Hypophosphataemia

\begin{tabular}{|c|c|c|c|}
\hline Main Cause & Secondary Cause & No. of Cases & Percentage \\
\hline \multirow[t]{2}{*}{$\begin{array}{l}\text { Intravenous } \\
\text { carbohydrate }\end{array}$} & $\begin{array}{l}\text { None } \\
\text { Vomiting } \\
\text { Nasogastric suction } \\
\text { Gram-negative septicaemia } \\
\text { Insulin } \\
\text { Vomiting + insulin } \\
\text { Acute bacterial endocarditis } \\
\text { Vomiting + cirrhosis }\end{array}$ & $\begin{array}{r}25 \\
3 \\
7 \\
1 \\
1 \\
1 \\
1 \\
1\end{array}$ & $\begin{array}{r}62.5 \\
7.5 \\
17.5 \\
2.5 \\
2.5 \\
2.5 \\
2.5 \\
2.5\end{array}$ \\
\hline & Total & 40 & 100 \\
\hline \multirow[t]{2}{*}{ Vomiting } & $\begin{array}{l}\text { None } \\
\text { Gram-negative septicaemia }\end{array}$ & 11 & $\begin{array}{r}91 \cdot 5 \\
8.5\end{array}$ \\
\hline & Total & 12 & 100 \\
\hline
\end{tabular}

In the remaining 26 cases no definite cause for the hypophosphataemia could be found. However, in most of these cases factors were present which have been reported as influencing the serum phosphorus level or the urinary excretion of phosphorus. (For various reasons it was not possible to perform urinary or other investigations on these patients.) Six had myocardial infarcts (without heart failure), two had clinical gout, and one had a severe urinary infection. Many were on thiazides, frusemide, or digoxin, and one was on acetazolamide. One was taking dienoestrol for prostatic carcinoma, one anabolic steroids for aplastic anaemia, and one adrenaline and another ephedrine for asthma. Eight had hypokalaemia and five an alkalosis. In only four cases could none of these possible causative factors be found.

Serum potassium was estimated in 65 cases in the diagnosed and 20 in the undiagnosed group. The incidence of hypokalaemia was $40 \%$ in both instances (26 cases and 8 cases respectively).

\section{HYPERPHOSPHATAEMIA}

Conditions (other than renal failure) known to cause an increase in the serum phosphorus level were present in $41(48.8 \%)$ of the 84 patients in this group (see Table III). Examination of the remaining 43 for possible causative factors showed that four had heart failure (three right-sided and one left-sided), eight

TABLE III-Causes of Hyperphosphataemia in 84 Cases

\begin{tabular}{|c|c|c|c|c|c|}
\hline \multicolumn{5}{|c|}{ Cause } & \multirow{2}{*}{ No. of Cases } \\
\hline Adolescence & .. & .. & .. & .. & \\
\hline High milk intake & . & .. & .. & .. & 6 \\
\hline Phosphate therapy & .. & .. & .. & . & 3 \\
\hline Vitamin D therapy & . & .. & .. & .. & 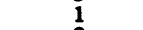 \\
\hline Diabetic coma & .. & .. & .. & . & 3 \\
\hline \multicolumn{5}{|l|}{ Bone tumour: } & \\
\hline Chondrosarcoma & & $\because$ & $\because$. & $\because$ & 2 \\
\hline Hyperthyroidism & - & .. & . & .. & 3 \\
\hline Hypoparathyroidism & & .. & .. & .. & 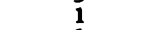 \\
\hline Heparin administration & & .. & .. & .. & 1 \\
\hline Leukaemia $\quad \because$ & & .. & .. & .. & 1 \\
\hline Haemolysed specimen & .. & .. & . & . & $?$ \\
\hline transfusion & .. & .. & . & . & \\
\hline matoma & . & .. & . & .. & 3 \\
\hline \multicolumn{6}{|c|}{$\begin{array}{l}\text { Haemolytic state: } \\
\text { Paroxysmal nocturnal haemoglobinuria }\end{array}$} \\
\hline Thalassaemia major & .. & .. & .. & $\because$ & \\
\hline Tealing fracture.. & . & .. & .. & .. & 2 \\
\hline & & .. & .. & .. & $4 \overline{3}$ \\
\hline
\end{tabular}

were receiving tetracyclines parenterally (six of these had obstructive jaundice, three of whom were recovering), one had gonadal dysgenesis, one had a probable carcinoma of the bladder, and one had shock resulting from burns to $60 \%$ of her body. Thus in no fewer than 28 cases the hyperphosphataemia remained completely unexplained.

\section{Discussion}

\section{HYPOPHOSPHATAEMIA: PROBABLE CAUSES}

Intravenous administration of carbohydrate was the commonest cause of hypophosphataemia. The effect was usually pronounced and in four patients the level was below $1.0 \mathrm{mg} / 100 \mathrm{ml}$. The fall in serum phosphorus level which accompanies carbohydrate infusion is due to the fact that phosphate accompanies glucose when the latter enters cells (Miller et al., 1952); this mechanism is responsible for the similar but milder effect noted in the first 45 minutes after a meal (Annino and Relman, 1959).

Vomiting is not usually mentioned as a cause of hypophosphataemia in most accounts of the subject. In 12 of our cases, however, it seemed the likely cause, as most of the patients had been vomiting repeatedly for several days and their phosphorus intake was probably very low. Both malabsorption syndromes and the administration of antacids that contain aluminium hydroxide (which binds phosphate in the intestinal lumen), may cause low serum phosphorus levels (Fauley et al., 1941). In these conditions the situation may be regarded as being similar to that in vomiting and in nasogastric aspirationnamely, an unavailability of phosphate for absorption into the blood stream.

Hypophosphataemia has been reported in severely decompensated cirrhosis of the liver by Amutzio et al. (1952) and Frank and Kern (1962). The exact mechanism is unknown. Amutzio et al. discussed the possible role of decreased dietary intake, steatorrhoea, and renal loss, whereas Frank and Kern attributed it to either coincident intravenous glucose therapy or respiratory alkalosis. Only one of our six patients was on intravenous therapy and was vomiting, but four had hypokalaemia. (The patients of Amutzio et al. also had abnormally low levels of serum potassium.) The possible role of hypokalaemia in the causation of hypophosphataemia is discussed below.

Another of our patients was suffering from acute alcoholic intoxication, with a serum phosphorus level of $1.2 \mathrm{mg} / 100 \mathrm{ml}$. Stein et al. (1966) reported hypophosphataemia in 23 out of 74 cases of acute alcoholism with no other known causes of hypophosphataemia. In all the level rose spontaneously to normal within a few days.

Riedler and Scheitlin (1969) reported hypophosphataemia in 22 out of 54 cases of Gram-negative septicaemia. Many of the patients were receiving intravenous infusions, but the hypophosphataemia could often be demonstrated before the therapy was started. They thought that a disturbance in carbohydrate metabolism, induced by Gram-negative bacterial endotoxin, was a possible explanation. We had three patients with Gramnegative septicaemia, but one was receiving intravenous glucose at the time and another had been vomiting. In the third case no other cause could be found.

\section{HYPOPHOSPHATAEMIA: POSSIBLE CAUSES}

Gilbert et al. (1970) noted an increased incidence of hypophosphataemia in patients with myocardial infarction, and Lehr et al. (1966) reported low serum phosphorus levels in experimentally induced disseminated myocardial necrosis in rats, though in the latter case the hypophosphataemia could have been due to the massive dose of catecholamines used to produce the necrosis (Goodman and Gilman, 1965).

De Oliveira and Laus-Filho (1961) reported low serum phos- 
phorus levels in 8 out of 11 patients with untreated gout. They considered that this may have been due to renal loss of phosphate resulting from tubular damage.

The intravenous administration of thiazides has been shown to produce an increase in urinary excretion of phosphorus (Duarte and Bland, 1965) and to reduce the plasma phosphorus level in dogs (Duarte, 1968). Condon and Nassim (1970) reported hypophosphataemia in humans treated with bendrofluazide for hypercalciuria; they attributed this either to thiazide-induced hypokalaemia or to direct stimulation of the parathyroid glands by the drug.

An increase in the urinary excretion of phosphate, but with no significant change in the plasma phosphorus level, has been demonstrated in humans treated with frusemide and with acetazolamide (Puschett and Goldberg, 1968) and in rats given an infusion of digoxin (Kupfer and Kosovsky, 1965). The administration of two or more of these drugs simultaneously, together with other factors such as myocardial infarction and hypokalaemia, as in some of our patients, could possibly result in a large enough urinary loss of phosphorus to produce hypokalaemia.

Another reported cause of hypophosphataemia is the administration of oestrogens (Parfitt, 1965) or androgens (Lafferty et al., 1964). In one patient the sole factor present was a severe urinary infection, and severe infections are known to produce hypophosphataemia (Gonzalez et al., 1964; Riedler and Scheitlin, 1969). Adrenaline can cause a lowering of the plasma phosphorus level (Goodman and Gilman, 1965). This is presumably due to the rise in blood glucose which it produces and is analogous to the effect of intravenous glucose. One of our patients had been given adrenaline and another ephedrine, both for acute asthma.

The association of hypophosphataemia with hypokalaemia, which was present in 34 patients, may have been fortuitous, and the incidence in the undiagnosed group $(40 \%)$ was no higher than that in the group with definite alternative causes for the hypophosphataemia. On the other hand, the possibility that hypokalaemia may itself be a cause of hypophosphataemia is suggested by the findings of Anderson et al. (1969), who reported low serum phosphorus levels, associated with increased urinary phosphorus excretion, in 13 patients with hypokalaemia due to a variety of causes, in 10 of whom the levels rose on correction of the potassium level with oral Slow-K. These results were confirmed by Condon and Nassim (1970), who noted a persistent fall in serum phosphorus of more than $1 \mathrm{mg} / 100 \mathrm{ml}$ in seven patients taking bendrofluazide for hypercalciuria. They thought that an intracellular potassium deficiency over a long time might cause renal tubular damage, resulting in a renal tubular phosphate leak.

Other possible causes of hypophosphataemia could not be ruled out in either of these series. However, in the case reported by Vianna (1971) of a patient who developed hypophosphataemia secondary to hypokalaemia and alkalosis after long-standing ingestion of liquorice and hydrochlorothiazide, and whose phosphorus level rose to normal after correction of the potassium deficit, no other possible causative factors were present. Vianna discarded the possibility that the thiazides, the liquorice, or the alkalosis caused the hypophosphataemia and postulated a similar mechanism to that suggested by Condon and Nassim (1970) - namely, a renal phosphate leak. Thus hypokalaemia seems to be established as a cause of hypophosphataemia and may be the factor operating in severe liver disease or in the administration of thiazides. The effect is probably due to increased renal excretion but may also be due to the alkalosis which often develops in potassium deficiency.

Acute respiratory or metabolic alkalosis has been shown by Mostellar and Tuttle (1964) to depress plasma phosphorus concentration. These workers postulated an exchange for lactate in the soft tissues, but other groups of workers have postulated a shift of phosphate into the cells (especially the erythrocytes) in association with the buffering of the extracellular alkalosis (Okel and Hurst, 1961; George et al., 1964). Other postulated mechanisms include a direct effect of the muscular exercise involved in producing the respiratory alkalosis (Saltzman et al., 1963) and stimulation of glycolysis by the alkalosis (Okel and Hurst, 1961).

\section{HYPERPHOSPHATAEMIA: PROBABLE CAUSES}

In seven cases the serum phosphorus level, though increased according to the criteria adopted in this study, was in fact normal for the age of the patients (13-17 years). Greenberg et al. (1960) showed that below the age of 20 the upper limit of normal for serum phosphorus is greater than $5.0 \mathrm{mg} / 100 \mathrm{ml}$, and at 10 years it is about $5.5 \mathrm{mg} / 100 \mathrm{ml}$. This is presumably due to the high rate of skeletal growth.

Six patients were taking $150 \mathrm{ml}$ of milk per hour for peptic ulcer. Allowing eight hours for sleep, this would give a total intake per day of $2,400 \mathrm{ml}$ (about 41 pints). This quantity of milk contains about $2,300 \mathrm{mg}$ of phosphorus (Thomas and Corden, 1970). As Smith and Nordin (1964) have shown that a dietary supplement of $1.5 \mathrm{~g}$ of phosphorus per day causes a significant increase in plasma phosphorus, the amount of milk drunk by our patients was sufficient to have produced the same effect despite the fact that two were also taking aluminium hydroxide gel.

The administration of phosphate and of vitamin D are known causes of hyperphosphataemia, as are diabetic coma and neoplasms involving bone. Less well known, however, is hyperthyroidism (Cook et al., 1959; Friis, 1961), the mechanism being probably related to the osteoporosis which occurs in this condition.

One of our patients was receiving intravenous heparin for a pulmonary embolus. McGeown et al. (1955) showed that phosphates present in commercial preparations of heparin could raise the serum phosphorus level.

Another documented cause of hyperphosphataemia is leukaemia (Jordon, 1966). We had one patient in this category, a 60-year-old man with acute myeloid leukaemia and a serum phosphorus level of $7 \cdot 1 \mathrm{mg} / 100 \mathrm{ml}$. Another man with hyperphosphataemia had chronic lymphatic leukaemia, but he was being treated with oral neutral phosphate for hypercalcaemia.

The red blood cells contain large amounts of phosphoruscontaining compounds mainly of the organic type. These are subject to hydrolysis, and the inorganic phosphorus content of whole blood held at $37^{\circ} \mathrm{C}$ can double in a few hours (Henry, 1964). Therefore it is not surprising that a haemolysed specimen will have a high phosphorus level, and a formula has been devised which corrects for the degree of haemolysis (Mather and Mackie, 1960). Blood transfusion may produce hyperphosphataemia (Bunker, 1966), presumably by the same mechanism, but the question of whether a haemolytic anaemia or a large haematoma can produce hyperphosphataemia is not so easy to answer. We had three examples of haematoma, but one of the patients, a haemophiliac, was a 14-year-old boy, and the high phosphorus level could have been due to his age. Similarly, one of our two patients with a haemolytic process (thalassaemia major) was a 16-year-old girl.

\section{HYPERPHOSPHATAEMIA: POSSIBLE CAUSES}

Some evidence has been put forward by Gilbert et al. (1970) suggesting that heart failure may be associated with high serum phosphorus levels, possibly due to reduced glomerular filtration, though all of our four patients with cardiac failure had a normal blood urea nitrogen level.

Tetracyclines have been noted to cause hyperphosphataemia, but usually by producing renal damage (Christian, 1970). None of our eight patients on tetracyclines were uraemic, but in three instances the increase in serum phosphorus occurred within a day of starting intravenous Reverin (rolitetracycline) therapy and usually persisted. 
One patient had severe shock due to $60 \%$ burns but was not uraemic. The patients of Schumer and Nyhus (1970) with oligaemic shock had high serum phosphorus levels (actual values not stated) which rapidly returned to normal when they were given corticosteroids.

\section{Conclusion}

This study shows that the causes of both an increase and a decrease in the serum phosphorus concentration are varied. The main clinical importance of this estimation at the present time is still in the diagnosis of hyperparathyroidism and hypoparathyroidism. However, the clinician must be aware of the other factors which affect the serum phosphorus level. In many cases there is no explanation for the change, and further work needs to be done in order to determine the effects of various diseases and drugs on phosphorus metabolism.

Requests for reprints should be sent to Dr. M. G. Betro, Institute of Medical and Veterinary Science, P.O. Box 14, Rundle Street, Adelaide, S.A., 5000, Australia.

\section{References}

Amutzio, D. S., Stutzman, F., Shrifter, N., and Nesbitt, S. (1952). Fournal of Laboratory and Clinical Medicine, 39, 26

Anderson, D. C., Peters, T. J., and Stewart, W. K. (1969). British Medical fournal, 4, 402.

Annino, J. S., and Relman, A. S. (1959). American fournal of Clinical Pathology, 31, 155 .

Bunker, J. P. (1966). Anesthesiology, 27, 446.

Carruthers, B. M., Copp, D. H., and McIntosh, H. W. (1964). Fournal of Laboratory and Clinical Medicine, 63, 959

Christian, D. G. (1970). American fournal of Clinical Pathology, 54, 118.

Condon, J. R., and Nassim, R. (1970). British Medical fournal, 1, 110.

Cook, P. B., Nassim, J. R., and Collins, J. (1959).Quarterly fournal of Medicine, 28, 505

Duarte, C. G. (1968). Metabolism: Clinical and Experimental, 17, 420.

Duarte, C. G., and Bland, J. H. (1965). Metabolism: Clinical and Experimental, 14, 211.

Fauley, G. B., Freeman, S., Ivy, A. C., Atkinson, A. J., and Wigodsky, H. S. (1941). Archives of Internal Medicine, 67, 563.
Fourman, P., and Royer, P. (1968). Calcium Metabolism and the Bone, 2nd edn. Oxford, Blackwell Scientific.

Frank, B. W., and Kern, E. (1962). Archives of Internal Medicine, 110, 865.

Fraser, F., and MacIntyre, I. (1970). In Biochemical Disorders in Human Disease, ed. R. H. S. Thompson and I. D. P. Wootton, 3rd edn. London, Churchill.

Friis, T. (1961). Danish Medical Bulletin, 8, 72.

George, W. K., et al. (1964). New England fournal of Medicine, 270, 726

Gilbert, F. E., Casey, A. E., Downey, E. L., Thomason, S., and Deacy, J. V. (1970). Alabama fournal of Medical Sciences, 7, 343 .

Gonzalez, C. F., Finberg, L., and Bluestein, D. D. (1964). American fournal of Diseases of Children, 107, 476

Goodman, L. S., and Gilman, A. (1965). The Pharmacological Basis of Therapeutics, 3rd edn. New York, Macmillan.

Greenberg, B. G., Winters, R. W., and Graham, J. B. (1960). Fournal of Clinical Endocrinology and Metabolism, 20, 364.

Henry, J. B. (1969). In Clinical Diagnosis by Laboratory Methods, ed. I Davidsohn and J. B. Henry. 14th edn. Philadelphia, Saunders. Henry, R. J. (1964). Clinical Chemistry, Principles and Technics. New York,

Hoffman, W. S. (1970). The Biochemistry of Clinical Medicine, 4th edn. Chicago, Year Book Medical Publishers.

Jordon, G. W. (1966). American Fournal of Medicine, 41, 381.

Kupfer, S., and Kosovsky, J. D. (1965). Fournal of Clinical Investigation, 44, 1132.

Lafferty, F. W., Spencer, G. E., and Pearson, O. H. (1964). American fournal of Medicine, 36, 514

Lehr, D., Krukowski, M., and Colon, R. (1966). Fournal of the American Medical Association, 197, 105.

Lancet, 1970, 1, 820.

McGeown, M. G., Martin, E., and Neill, D. W. (1955). Fournal of Clinical Pathology, 8, 247.

Mather, A., and Mackie, N. R. (1960). Clinical Chemistry, 6, 223.

Miller, M., Drucker, W. R., Owens, J. E., Craig, J. W., and Woodward, H. (1952). Fournal of Clinical Investigation, 31, 115

Mostellar, M. E., and Tuttle, E. P. (1964). Fournal of Clinical Investigation, 43, 138.

Okel, B. B., and Hurst, J. W. (1961). Archives of Internal Medicine, 108, 157.

Oliveira, H. L. de, and Laus-Filho, J. A. (1961). Lancet, 2, 215.

Parfitt, A. M. (1965). Fournal of Bone and foint Surgery, $47 \mathbf{B}, 137$.

Puschett, J. B., and Goldberg, M. (1968). Fournal of Laboratory and Clinical Medicine, 71, 666 .

Riedler, G. F., and Scheitlin, W. A. (1969). British Medical fournal, 1, 753

Saltzman, H. A., Heyman, A., and Sieker, H. O. (1963). New England Fournal of Medicine, 268, 143

Schumer, W., and Nyhus, L. M. (1970). Archives of Surgery, 100, 405.

Smith, D. A., and Nordin, B. E. C. (1964). Clinical Science, 26, 479.

Stein, J. H., Smith, W. O., and Ginn, H. E. (1966). American fournal of the Medical Sciences, $252,78$.

Thomas, Sucy, and Corden, Margaret. (1970). Tables of Composition of

Vianna, N. J. (1971). Fournal of the American Medical Association, 215, 1497.

\title{
Benzhexol and Side Effects with Long-acting Fluphenazine Therapy
}

\author{
LYNN GROVE, J. L. CRAMMER
}

\section{British Medical fournal, 1972, 1, 276-279}

\section{Summary}

Sixteen patients who had for some months been on fluphenazine enanthate injections $(1-3 \mathrm{ml})$ every two or three weeks, with daily oral benzhexol (6-40 mg), were divided into two groups comparable in age, diagnostic category, and drug dose.

Placebo was substituted under blind controlled conditions for benzhexol in one group, and both groups were regularly assessed by Simpson rating scale for extrapyramidal signs, and by a 30 -question symptom check list. Both assessments were found reliable.

Four out of eight patients had severe reactions when off

St. John's Hospital, Stone, Aylesbury, Bucks.

LYNN GROVE, M.B., B.S., Registrar

J. L. CRAMMER, M.R.C.S., L.R.C.P., D.P.M., Consultant (Present appointment: Senior Lecturer, Institute of Psychiatry, London) benzhexol, but symptoms such as tremor and daytime sleepiness were unaltered in all patients. The other four did not suffer adversely from withdrawal of benzhexol.

Acute withdrawal is therefore unjustified, but occasional revision of dosage of anti-Parkinsonian drugs is advisable. There is no evidence that tolerance develops to any effect of a phenothiazine, but long-continued benzhexol might induce a denervation supersensitivity. It is also possible that Parkinsonian signs are dependent on affective state.

\section{Introduction}

When the long-acting phenothiazine fluphenazine enanthate was first introduced for the treatment of psychosis by single intramuscular injections spaced weeks apart it was feared that the severity of the side effects commonly produced would make the drug unacceptable to patients. Kinross-Wright et al. (1963), in a trial in 147 patients, noted extrapyramidal reactions, chiefly of the episodic dystonic type, in over half of them, and 